This article was downloaded by: [New York University]

On: 11 May 2015, At: 18:57

Publisher: Routledge

Informa Ltd Registered in England and Wales Registered Number: 1072954

Registered office: Mortimer House, 37-41 Mortimer Street, London W1T

3J H, UK

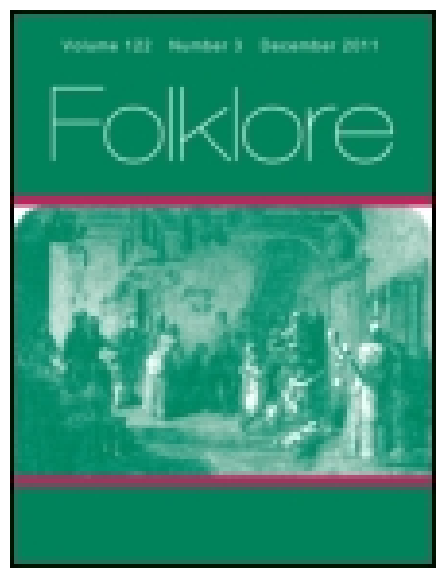

\title{
Folklore
}

Publication details, including instructions for authors and subscription information:

http:// www. tandfonline.com/loi/ rfol20

\section{English Folk-Drama}

T. Fairman Ordish

Published online: 14 Feb 2012.

To cite this article: T. Fairman Ordish (1893) English Folk-Drama, Folklore, 4:2, 149-175, DOI: 10.1080/ 0015587X.1893.9720150

To link to this article: http:// dx. doi. org/ 10.1080/0015587X.1893.9720150

\section{PLEASE SCROLL DOWN FOR ARTICLE}

Taylor \& Francis makes every effort to ensure the accuracy of all the information (the "Content") contained in the publications on our platform. However, Taylor \& Francis, our agents, and our licensors make no representations or warranties whatsoever as to the accuracy, completeness, or suitability for any purpose of the Content. Any opinions and views expressed in this publication are the opinions and views of the authors, and are not the views of or endorsed by Taylor \& Francis. The accuracy of the Content should not be relied upon and should be independently verified with primary sources of information. Taylor and Francis shall not be liable for any losses, actions, claims, proceedings, demands, costs, expenses, damages, and other liabilities whatsoever or howsoever caused arising directly or indirectly in connection with, in relation to or arising out of the use of the Content.

This article may be used for research, teaching, and private study purposes. Any substantial or systematic reproduction, redistribution, reselling, loan, sub-licensing, systematic supply, or distribution in any form to anyone is 
expressly forbidden. Terms $\&$ Conditions of access and use can be found at http://www.tandfonline.com/page/terms-and-conditions 


\section{ENGLISH FOLK-DRAMA.}

II.

$\mathrm{B}^{\mathrm{EFORE}}$ plunging into the second instalment of my notes on what I call English Folk-Drama, I should like to say that, in addressing folk-lorists on such a subject, I lay claim to no particular knowledge, but fully recognise that amongst those present at this meeting there are probably some whose knowledge of these traditions is morc extensive than mine, whose insight into their import is deeper and more widely reaching, whose skill in handling the instruments of the folk-lore laboratory is more expert. But, knowing as I do-as no doubt you all do-that these traditions, within the last few years, have been exhibiting signs of rapid decay, I am glad to be the humble means of introducing the subject to the consideration of the Society this evening, knowing well that my deficiencies will be made good from the knowledge of those whom I am addressing. I may say at once that this will be the burden of my remarks-the value of folk-drama as a vehicle of tradition; the bearing and influence-undoubted in my mind-of folk-drama upon the evolution of the drama of our nation; the very incomplete collection which has been made of the various forms or phases of folk-drama ; their present alarmingly rapid decay. I am convinced that if a systematic collection had been made after Mr. -Udal gave us his very interesting paper on the MummingPlays of Dorsetshire in 1880 , much that is now irretrievably lost would have been on record. It is not only that the traditions have utterly died out in so many districts,

1 A paper read before the Folk-lore Society, Febranry 15th, 1893 . vol. IV. 
but in other places where they have survived they have become attenuated, and show an altogether feeble existence compared with what they were only a few years ago. The urgency of appeal which lies in these circumstances will, I am sure, be felt by the Folk-lore Society, and I will not harp upon the string of lamentation throughout the short time at my disposal. Indeed, to show the rewards which await the collector even now, I have a few freshlygathered items to bring before you this evening, along with two dresses worn by English folk-players, and some photographs. What I shall have to urge is that the Society spread its net-which it can now effectively do by means of its local organisation-all over the country, and collect together all the fragments of folk-drama and dramatic custom which remain to us.

It would be taking a very limited view of folk-drama if we were to restrict our attention to what are known as the mumming-plays associated with Christmastide. But they are the most generally known-indeed, I fear that by some they are considered to represent the whole stock of English folk-drama-and I will address myself to this class of folk-play first. Well known as they are, I do not think the traditional import of these plays is always considered. When Mr. Christopher Burne, with our esteemed Secretary, and their friends, gave us a reproduction of the Staffordshire variant of the mumming, called the Guisers' Play, in Mercers' Hall, it was said, in my hearing, by a distinguished folk-lorist, with a somewhat -weary air of disappointment, "It's all St. George and the Dragon." This seems to suggest the advisability of taking some account of the traditions which have descended to us through the means of the mumming-plays happily not yet extinct in our land.

Throughout a long period in our history, beginning as far back as the Conquest, we can trace the operation of a process by which traditional observances, at one time marking various stages in the year's passage, gradually 
became concentrated upon one or more festivals, chiefly Christmas and Easter. The result of this process-due to economical and political causes-was a mixture of rites, observances, and celebrations; so that in the mummingplays we have rites of Yule-tide, along with dramatic reminiscences of the legend of St. George, which figures more individually in connection with Easter. But, if we take the St. George element of the Pace-Egg and the mumming-plays, and, collating them, compare the result with the earliest recorded dramatic presentation of the legend of St. George and the Dragon, we find that various features have been added, and, of these features, that some are common to both types, while in all important instances they are archaic, and belong to the earliest traditions.

But, granting for the moment that the main stem of the mumming-play is the legend of St. George, what does that represent, to begin with? It is an example of the skill with which the Church supplanted the pagan Pantheon. Yet was the policy hardly so successful as it appeared to be. For whether St. George represents the adoption by the Church of an important feature in the Northern mythology under another name, or the legend were of Eastern or Southern origin, the effect and result were the same. Under the first hypothesis we have Northern paganism thinly disguised; under the second we have a legend adopted in the country because it recognisably represented, let us say, Odin and his horse Sleipner, and the dragon suggested the dragon Nidhug, which dwelt by the fountain Hvergelmer in Niflheim. To dismiss the first hypothesis does not dispose of the second; and to prove that St. George was a Christian product would not dispose of the circumstance that, while the missionaries taught one thing, the folk were thinking of something else, superficially very much like it, but in fact totally different. On the supposition, then, that the main stem of the mummingplay is the St. George and Dragon legend, it places us in connection with the earliest history of our race in this 
country. Indeed, if we trace the course of its descent, we find that it has reverted to its original type, to use a cant phrase in science; more correctly, it has thrown off the cloak fastened upon it by the Church, and now, in this $f(n$ de siècle period, when Culture is cultivating æesthetic Paganism, the mumming-play of the backward class, as it is distinguished by some folk-lorists, has become more pagan. The dragon, conflict with which may have symbolised some spiritual idea, has disappeared, and the mummers fight together with high boasting; they glory in their deeds; and when they are slain they do not die, but live to fight again. This is a reversion to something extremely like Valhal. I trust the folk-lorists of a future age will not connect it with the asthetic paganism of our time.

As we are entering the warlike atmosphere of the Northern mythology, I will not lack boldness, but will for a moment refer to the instances of the pageant of St. George in the fourteenth and fifteenth centuries, mentioned in my previous paper, as it was performed when the Roman Church was at the height of its power, and the St. George's pagcant had its place among the miracle-plays which were an institution in the land. In these instances we have the Christian knight rescuing the King of Egypt's daughter from the dragon; but even here there is an element that betrays the northern soil into which the legend was transplanted. The representations invariably took place by a well or water-conduit; and the association with the dragon suggests the fountain. Hvergelmer, and its guardian or tenant, the dragon Widhug, or possibly Thor overcoming the serpent Midgard, whom he slew in the waters ?

So much at present for the pageant of St. George and the Dragon, reminiscences of which, as it was performed by the Guilds of St. George on April 23rd, we find in the Christmas mumming-plays. But how short of the truth it is to say that these plays consist of nothing but the St. George and Dragon legend, will appear as the analysis proceeds. 
Of the three important divisions or types of English folkdrama, viz., the Christmas Mumming-play, the PloughMonday Play, and the Easter or Pace-Egg Play, the first and the last contain the character of St. George, with allusions to the legend, while in the Plough-Monday play that element is absent. But there is another element, which is common to all three groups, and that is the sworddance. In the northern counties-Durham, for examplethere is a sword-dancer's play or interlude, performed at Christmas, in which the traditional movements and evolutions of the sword-dance take place to the accompaniment of a song by the chief character, who is strictly the chorus of the piece, for he characterises each of the characters as they step in and join the performance. At the end of the dance the carefully concerted movements are abandoned, and fighting ensues : the parish clergyman rushes in to prevent bloodshed, receives a death-blow, and is cured by a doctor. Even from this description it is obvious that, in spite of the absence of St. George, this play presents points of resemblance to both the Mumming and the Pace-Egg types. First, a circle is drawn by one of the characters with his sword, and the performance takes place within that circle: the mumming and Pace-Egg plays are invariably prefaced by one of the characters claiming a space for the performance, sometimes with a broom sweeping round a circle, sometimes by "footing it round", as it was called; second, the characters fight together-in the mumming and Pace-Egg types they fight in couples successively; third, the doctor cures the slain-this feature is practically the same in the sword-dance play, and the mumming and Pace-Egg plays.

This sword-dance Christmas play found its way as far south as Devonshire; while versions of the mumming and Pace-Egg plays obtained in all parts of the country. The sword-dance itself, which underlies them all, continued its traditional existence chiefly, if not entirely, in the northern counties. 
It will be seen that the Christmas mumming-play in its various forms is not all St. George and the Dragon. It is not all of anything-but an amalgam. The word "mumming" itself puts us upon the trail of another of its elements, that is, the disguising or masking. The masks were made in imitation of various animals-goats, oxen, deer, foxes, asses, and what not-a custom which found its niche of immortality in the palace of Shakespeare's creations, in the person of Bottom the weaver. The wearing of such masks is essentially of savage origin, and, because their survival has entered into the pageantry of the dominant classes of society, it has never occurred to me to suppose that the stationary portion of society received them by a process of precipitation from the top stratum of the social systemalthough I quite expect to hear that view propounded presently. I should as soon be convinced that heraldry, instead of being a development from totemism, set the fashion of wearing totem signs, which gradually percolated down to savagery. The wearing of masks by the mummers has died out to a great extent, but I do not think it is extinct ; there are several recorded cases within the present century. The disguising, or wearing of strange dresses, continues apparently without diminution. In the demand for drink usually made by the first mummer who enters, and the songs sung in several versions, we have the survival of the rite of the wassail-bowl.

There remains to be considered the structure of the typical mumming-play-the characters represented, the dialogue, and development of the action. All this presents only slight variations from the Easter or Pace-Egg play. By the operation of that law of concentration which we have already discussed, the Pace-Egg play, from being performed at Christmas, became mixed up with the mumming or guizing - that is, disguising-and this mixture is the typical Christmas mumming-play, which is regarded as being nothing more interesting than a debased rendering of the pageant of St. George and the Dragon. 
The Easter, or Pace-Egg play-so called from its being performed in connection with the well-known custom of Pace-Egging-now calls for our notice, and must take us for the time from Christmas and the mumming-play. Collating two versions of the play (which have found their way into print, and copies of which I exhibit), we find it contains the following characters: Fool; St. George; Slasher; Doctor; Prince of Paradine ; King of Egypt ; Hector; Beelzebub ; Devil-Doubt. The action consists of a fight between St. George and Slasher; Slasher being wounded, is cured by a doctor. Then St. George boasts as follows :

"I am St. George, that noble champion bold,

And with my trusty sword I won ten thousand pounds in gold. 'Twas I that fought the fiery dragon, and brought him to the slaughter,

And by those means I won the King of Egypt's daughter."

Whereupon the Prince of Paradine enters, and, after exchanging defiance, in course of which St. George calls the prince "thou black Morocco dog", they fight, and the prince is slain. Then we get a palpable interpolation ; for the King of Egypt comes in and laments the prince as his son, calling upon Hector to come and avenge him. So that St. George, having won the King of Egypt's daughter, slays his son. Moreover, the king calls St. George "cursed Christian". In this we can perceive the clumsy joinery of the Crusade element and the pageant of St. George and the Dragon. The next point in the action is the fight between St. George and Hector, who goes off wounded. The Fool then challenges St. George, who says :

"I'l cross the water at the hour of five, And meet you there, Sir, if I be alive,"

and goes off, having occupied the stage from the beginning. The play concludes with the entry of Beelzebub, whose business it evidently was to raise a laugh, and little 
Devil-Doubt with his broom comes in to receive the largess of the spectators.

Now, at a first glance, that looks as if it were all made up of reminiscences of the St. George and Dragon pageant and the Crusades. People who would hail that interpretation with satisfaction, conceive all such things as having an individual origin. Some individual composed that pageant of St. George; some other individual composed a play about the Crusades; and the stupid, ignorant people mixed it all up. The other method of interpretation takes a wider view. It proceeds upon a generalization of all the past of human life, which shows collectively a faculty of continuity throughout the generations of men : a continuity which leads to the conception of the individuality of human life as a whole, and causes disbelief in sudden and arbitrary origins. It is a conception strictly in accord with the observed phenomena of nature-the seed, the tender shoot, the sapling, the tree, maturity-the seed to the ground; the process repeated; and with this identity modifications occurring with a slowness which it requires a great effort to realise. Let us look a little deeper into this Easter play, and not hastily accept an explanation because it is obvious and simple. Let us look for continuity, and not accept modification for origin.

The Pace-Eyg play was performed at Easter. The Christian Easter was fastened upon the Aryan Spring festival, substituting for the celebration of the regeneration of nature the more spiritual celebration of the immortality of the soul of man, so that the egg which symbolised the one attained a higher significance in the other. But the connection between them is indisputable: there is continuity and modification. Similarly, in the Easter or PaceEgg play the Aryan root of the matter remained under changed conditions and altered signification, as may be illustrated from the Northern mythology.

The Elder Edda thus refers to the death of Balder, the personification of summer and light : 


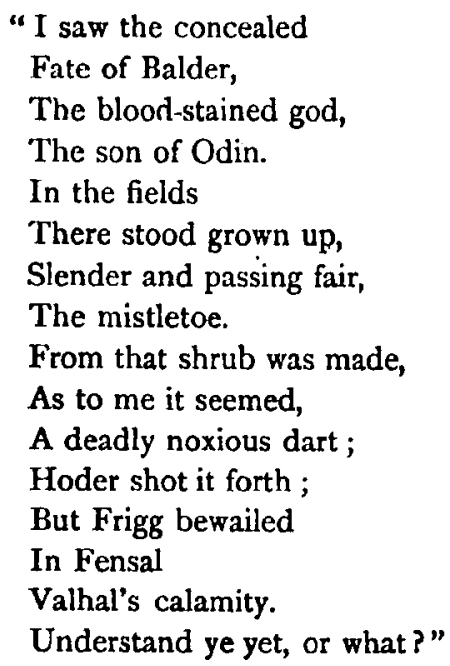

In the Balder myth, Hermod undertakes to ride to the lower world and offer a ransom to $\mathrm{Hel}$ if she will permit Balder to return to Asgard. He mounts Odin's horse Sleipner and gallops off on his journey. Arrived at the abode of $\mathrm{Hel}$, he finds Balder occupying the most distinguished seat in the hall. To his entreaties for Balder's release, Hel replies that it should now be tried whether Balder was so universally beloved as he was said to be: if all things in the world, animate and inanimate, will weep for him, then he shall return to the gods ; but, if anything refuse to weep, Hel will keep him. Balder and his wife Nanna then give Hermod those keepsakes for Odin and Frigg, which are construed as earnests of their return, and Hermod rides back to Asgard. The gods then send messengers throughout the world, beseeching everything to weep, and men, animals, earth, stones, trees, metals, all willingly obey, except a giantess, Thok, supposed to be Loke Laufeyarson himself in another form, who caused the death of Balder, by the hand of Hoder, who threw the fatal mistletoe shaft.

The contest between Thok and Balder was represented 
at the Spring festival. Two champions were dressed up, one in foliage and flowers, the other in straw and moss, and the conflict of course ended in the victory of Balder, or Summer. This custom prevailed all over Norseland, in Germany, and in this country. In the myth, the victory over Thok is vague; but it seems to be implicated with Odin's victory over Vafthrudner by means of a riddle which led to the giant forfeiting his head. In the Easter play St. George says :

"I followed a fair lady to a giant's gate,

Confined in dungeons deep to meet her fate;

There I resolved, with true knight errantry,

To burst the door and set the prisoner free,

When a giant almost struck me dead,

But by my valour, 1 struck off his head."

I merely note this at present because, whether by accident or no, it contains allusions which appear to bear upon the Balder myth.

I note next these words spoken by Slasher in his defiance of St. George :

\author{
"How canst thou break my head? \\ My head is made of iron, \\ And my body's made of steel, \\ My hands and feet of knuckle-bone- \\ I challenge to make thee feel."
}

The allusion may be to armour. But if the allusions in the former passage spoken by St. George were proved to be derived from the myth, we should scarcely hesitate to identify Slasher with the champion of Winter, interpreting the iron and steel and knuckle-bone as descriptive of the frost-bound earth. We should then have in St. George and Slasher the renamed representatives of the two champions, Summer and Winter, whose contest was a principal feature in the Spring festival.

The next point to be noted is that the episode of the St. George and Slasher contest individualises itself in the 
Easter play. It ends in the cure by the doctor, who does not reappear to cure the subsequent combatants. In fact, so clearly is the episode marked off from the rest of the play, that, having noted the distinction from the internal evidence, I was not a little surprised to find afterwards that in the versions which $I$ exhibit it had been clearly differentiated by making it a separate and distinct act, the remainder of the play being called Act II.

The element of the doctor and his cure of the wounded or slain combatant is common to the sword-dance play, the Plough-Monday play, and the first portion of the Easter play. Whatever the vagaries of nomenclature may be-I am stating as briefly as possible the result of a very wide and extended collation of versions-we have here the trunk of this body of tradition. Around it all kinds of mutations and changes occur, but itself persists, because it is archaic. And it has nothing to do with the St. George and Dragon pageant, nothing to do with the Crusades. Take the rest of the Easter play-the second part-and you will find it quite distinct and separate, a thing made up of the pageant of St. George and the Crusades, with Beelzebub and the little Devil from some mediæval miracleplay. In the Easter play we have the elements of Pagan and Christian, as the egg, typical of the regeneration of life, became the symbol of the resurrection after death.

Before recurring to the Christmas mumming-piay, into which the Easter play was imported, let us finish the analysis. We have to account for the doctor who cures the wounded Slasher, and, on our theory of continuity, we have to account for the second portion of the play.

According to the traditions of the contest between the Winter and Summer champions, there were other combatants, armed with staves, who also contended, how, or in what order, is not known. This traditional contest was performed at some date very near St. George's Day, the 23 rd April, when the pageant was performed, to be followed a few days later by the May-Day games, which celebrated 
the victory of Summer. This presents us with the conditions of an amalgamation, which seems to have taken place at about the period of the Crusades. The Summer champion became St. George; St. George himself became the type or representative of England; and, in place of the dragon of the pageant, one or more of the combatants in the Winter and Summer contest represented Mohammedan warriors, over whom the Christian St. George of England is, of course, victorious. When the dialogue was added we do not know; there were probably spoken words of defiance by the champions in thirteenth-century English, and on this modifications and developments were made, until the play reached the shape in which we know it in more or less debased forms. But in the determination of that shape there was a factor which remains to be considered, and that was the sword-dance. In this performance a circle was drawn by the Chorus, called "First Clown" in the version given by Henderson in his Folk-lore of the Northern Counties, and "Captain" in the version in Sir Cuthbert Sharp's Bishoprick Garland, who, after walking round the circle, summons the other performers in verses of a song, as thus :

"Now, the first that I call on

Is George, our noble king;

Long time he's been at wars,

Good tidings back he'll bring."

The introduced actor walks round the ring, and the Chorus proceeds :

"The next that I call on

He is"-(so and so).

In this way all the characters are brought in before the concerted movements of the dance itself take place.

Now, the formula - "In comes I"-spoken by the characters as they enter in the Plough-Monday play, in which the element of the sword-dance is indisputable, supplies us with the development of dialogue from chorus. In the 
mumming-plays, the characters announce themselves in the same way. The sword-dance has retained the integrity of its descent more clearly than any of the other elements of folk-drama; and the association of swords and fighting in the Easter play suggests a connection with the sworddance, which becomes clearer upon examination. The Fool in the Easter play, who first enters and claims room for the play, summons St. George to enter; and this equates with the Chorus of the sword-dance, who summons the actors in turn. From this point the Fool is silent, and the characters announce themselves, as :

"I am the Black Prince of Paradine, born of high renown," and the familiar:

"In comes I, the Turkish Knight,"

of the mumming-play.

It seems to me we can see the ground-plan of the Easter play and the mumming-play in the sword-dance with its chorus. In fact, we have the chorus in the Easter play, as the Fool, a part taken by Father Christmas in the mumming-plays.

I have now exhausted the constituents of the Easter play, with the exception of the character of the Doctor, which factor I leave over to the Plough-Monday play, with which it is common.

That there was some form of dramatic representation at Christmas, on to which the St. George or Easter play was engrafted, is what the law of continuity with modification would lead us to expect; and what evidence we have points to this conclusion. Grimm tells us that "at Christmas a sacrificial play is still performed in parts of Gothland, acted by young fellows in disguise, who blacken and rouge their faces. One, wrapped in fur, sits in a chair as the victim, holding in his mouth a bunch of straw-stalks cut fine, which reach as far as his ears, and have the appearance of sow-bristles: by this is meant the boar sacrificed at Yule, which in England is decked with laurel 
and rosemary." Here we have the Scandinavian or Teutonic original of the mumming-play, with which the Scandinavian sword-dance became combined after passing through the Easter play. Henderson tells us that throughout Yorkshire mummers go round visiting at houses where they know they are likely to meet with entertainment, disguised in finery of different sorts, with blackened faces or masks, and carrying with them an image of a white horse. Mr. Baring Gould tells us that "at Wakefield and Stanby the mummers enter a house, and, if it be in a foul state, they proceed to sweep the hearth and clean the kitchen-range, humming all the time 'mum-m-m'." This seems to suggest some connection with the good fairies who perform tasks of housework if properly propitiated. In Scotland, where the mummers are called Gysards, when a party of these visitants enter a house, one of them precedes the rest, carrying a besom, and sweeps a ring or space for the Gysards to dance in. This ceremony is strictly observed; and it has been supposed is connected with the tradition concerning the light dances of the fairies, one of whom is always represented as sweeping the spot appropriated to their festivity. This may be so; but I am inclined to connect it with the sword-dance circle.

Summarising this analysis of the Christmas mummingplay, we find that it consists of the following elements combined by the natural dramatic instincts of the folk :-

(a) The Christmas Masking or Disguising.

(b) The Sword-Dance : the character of Father Christmas being a modification of the Chorus of the Sword-Dance Play.

(c) The Pace-Egg or Easter Play.

(d) The Wassailing Rite or Custom.

I will now communicate some versions of the Christmas mumming or masking play, which I have been the means of collecting during the last two years. I have two versions fresh from Hampshire this last Christmas, one collected by 
myself, together with a specimen of the dress worn by the actors of this version, which I exhibit, along with wooden swords used by them; the other communicated to me by Mr. S. Peppler of Hamble Cliff, near Southampton, together with photographs of the actors in this version, also exhibited.

I have also a version from Northamptonshire, kindly communicated to me by Miss Burne; and two versions communicated through Mrs. Gomme, one from Marlborough, sent by Mr. H. S. May, and another from Romsey, sent by Miss E. L. Merck.

[Extracts were read to the meeting; and the differences between the versions were pointed out. The mummer's dress was made in a scaly pattern throughout; and it was suggested that this device was intended to represent the dragon which no longer accompanies the mummers, a parallel to the dress of the Plough-Monday players.]

I have not succeeded in getting a printed version of the mumming-play in chap-book form like the two PaceEgg plays exhibited. The nearest approach to it is the curious little book called The New Christmas Rhyme Book, from Belfast, sent to Mrs. Gomme by Mr. W. H. Patterson. But I believe the mumming-play has been printed and sold as a chap-book; and this leads me to propound a question, to which, perhaps, some of our friends present would give an answer different from that which I should give. Does the fact of writing down or of printing destroy tradition? At the present time the mummingplay is performed in three ways-(a) by those who learn it from printed book; (b) by those who learn it from MS.; (c) by those who learn it by oral tradition. This seems to me to furnish an admirable test-case to the believers and unbelievers in literary origins.

The next branch of folk-drama on which I have to offer a few notes is the Plough-Monday play; and here I may proceed more summarily, as I do not conceive how the champions of literary origin can bring their battery to bear 
on this tradition. It has evolved and descended from Aryan custom, possibly some sacrificial rite in dramatic form to the goddess Gefjun, the goddess of agricultureGefjun personifying the ploughed land as Frigg represents the fruit-bearing earth. In the myth of Thor and Hrungner we see how the thunder god crushes the mountain of rock to prepare the way for agriculture; and the Gefjun myth about the ploughing with four oxen represents the subsequent tillage. In Blomefield's History of Norfolk we read: "Anciently, a light called the 'Plough Light' was maintained by old and young persons who were husbandmen, before images in some churches, and on Plough-Monday they had a feast, and went about with a plough and dancers to get money to support the plough-light. The Reformation put out these lights, but the practice of going about with the plough begging for money remains." No doubt the begging in the first place was for the maintenance of the lights, a derivation, possibly, of sacrifice to the goddess Gefjun.

The dancers alluded to by Blomefield were the sworddancers ; and here again we have the phenomena of amalgamation and continuity with modification. The result was a play called the Plough-Monday play, the process being analogous to that we have already discussed, where the sword-dance entered into and gave shape and coherence to existing dramatic traditions.

It is impossible for me to do more now than indicate the outline of this important branch of English folk-drama. With the plough we get the horse, and the horse again places us in connection with the fabulous horses of Aryan mythology. These godlike animals, commemorated in English traditions, become identified with the horses familiar in agriculture : thus we get the hobby-horse, and a whole cycle of observance, of which the effigy of a horse. or a horse's head, is the pivot. This element is a common factor in the problem of folk-drama ; this and the doctor who cures the wounded combatants, or raises them to life 
when slain, and both of them-like the sword-dance-take us straight back to Scandinavia. By way of illustrating this permanence of the archaic in dramatic tradition, let me select two instances. A version of the St. George drama is concluded with the introduction of a hobby-horse, over whom a song of several verses is sung, the horse snapping his jaws by way of chorus after each verse, by a device familiar on the stage, when Bottom in his ass's head moves the ass's jaws when speaking. The fourth verse is as follows :-

"Behold how this horse stands upon the stones I

He is short in the leg, but full in the bone, He has an eye like a hawk, a ear like a dove;

As many wrinkles in his forehead as there is in $2 n$ acre of ploughed ground."

That last line is an obvious interpolation, connecting the horse with the plough. In the whole song it is the only line which utterly escapes the metre. Counting the syllables, it makes about two-and-a-half lines of the verse in the rest of the piece. It is clearly an interpolation; it belongs to the traditionary observance which survived from the sacrificial rite to the Scandinavian goddess of agriculture.

Another instance : another version of the same song in another county. At the close of the song, which is one of lamentation over the poor old horse, past his prime, the animal, or rather its representative, drops down as if dead. Same dialogue ensues, the upshot of which is that the horse gets a new lease of life, like the wounded combatants in the St. George and mumming plays; and the horse proceeds to worry a blacksmith who endeavours to shoe him. The affair is concluded by the singing of the following stanza :-

"The man that shod this horse, Sir, That was no use at all, He likened to worry the blacksmith, His hammer and nails and all."

These lines, says the recorder, are sung with great noise voL. Iv. 
and histrionic display: for mentioning which fact I am extremely obliged to him; we know that noise and tumult were always associated with the traditions of Thor, and this episode presents in the blacksmith with his hammer a pretty clear reminiscence of Thor's connection with agriculture in the Scandinavian mythology.

I have mentioned these instances because they occur in dramatic songs, which at a superficial glance appear to be quite modern and commonplace, for which reason they admirably exemplify the survival of the archaic in the midst of later accretions.

It is with great pleasure that I bring to your notice now a version of the Plough-Monday play which has been communicated to me by Mrs. Chaworth Musters, along with the most interesting dress worn by the actors of this version as repeatedly witnessed by Mrs. Chaworth Musters at her residence, Wiverton Hall, near Bingham, Nottingham. shire. The version wears a modern look, but, like the hobby-horse performances just noticed, it has its elements of archaism which persist. I should like first to read an extract from a letter I received from Mrs. Musters, as it is in effect a message to the Society, and brings before us the aspects of the play as they impressed themselves on an eye-witness :-

"I hope that if all is well another year, I may have the pleasure of seeing some members of the Folk-lore Society here for Plough-Monday, and I hope the play will not die out in this neighbourhood for long, as the actors this time were all youths who had leamt their parts by word of mouth. I had some difficulty in getting a copy of the words a few years ago, as it seems never to have been written down; but I did get it, very ill-spelt and difficult to make out, except that I had heard it several times, and I had it printed in the appendix of a Notts story I wrote, so that it might be preserved. I enclose the book. The same version seems to be known in Lincolnshire, Leicestershire, and Northamptonshire. I wish I could have got a photograph of the performers, but they could only come in the evening, being farm 
labourers. The man who is called 'Hopper Joe' has a basket slung before him, as if he was going to sow seeds, in which you put any money you like to give. The sergeant gets hold of any bit of old uniform he can meet with, and the young lady always has a veil, Beelzebub a blacked face, and either a besom of straw or a club with a bladder fastened to the end of it. The chief feature of the play is the raising to life of the old woman(who is knocked down by Beelzebub) by the doctor, who is always dressed in the smartest modern clothes, with a riding-whip and top hat if possible. This year the men had no cut-out figures on their shirts, only ribbons and rosettes and feathers stuck in their hats, and the brass ornaments of their horse's hamess hanging down in front. But $I$ have generally seen them with small horses, and ploughs in red and black, stuck on. They do not bring a plough with them here. Little boys with ribbons on come round begging in all the villages in the vale of Belvoir here, on PloughMonday, but no women or girls ever seem to take part in it."

Mrs. Musters subsequently sent me the dress exhibited. In a letter which accompanied it she said: "The group of men are intended to represent the Plough-Monday boys. ....... The idea of the man who made it is that all the live creatures connected with a farm ought to be represented." Mrs. Musters also sent me a copy of the verses sung on the occasion of the play. These have never before been recorded. I exhibit the MS. of the Ploughman who sang them on Plough-Monday last, and who wrote them down for Mrs. Musters.

I also exhibit the figure of a horse cut out to be worn on the dress, which I received from Mrs. Musters before I received the dress. When I learnt from Mrs. Musters the interesting fact that although these players no longer bring a plough with them they figure it on the dress, $I$ begged her to obtain a specimen of the dress for exhibition this evening, a request with which she at once complied. It was made by the man from whom she had obtained the figure of the horse. The dress seems to present us with an example of picture-writing and such 
a survival must be very encouraging to the anthropologist and folk-lore collector. I shall hope to hear presently from the President and others their views on this point. It will be observed that the execution of the letters is not superior, but rather the reverse, to that of the figures.

[The scaly pattern of the mummer's dress from Hampshire was again referred to, and the likelihood of a similar desire for representation having caused this reminiscence of the dragon was pointed out.]

It is a curious fact to contemplate that at the present time we have in this country, living simultaneously in rural districts, representatives of two distinct levels of culture. There is the younger generation, equipped with a uniform education tending to make all minds of one type; and there is in the generation dying out a quite different mental aspect-a culture varying in degree and kind, but united by an underlying system of tradition. Picture-writing and gesture-language in the age of Board schools suggest conditions which may make us wonder if the law of continuity with modification is about to cease.

Quite recently, I heard of an interesting case of an old couple living in Surrey, between Woking and Guildford, which illustrates the use of picture-writing in the age of newspapers. The old lady always takes the Police News, and she explained to my friend that she does this because she hears the news from her neighbours who read the newspapers, and then she can take her picture-paper and make it all out. This is strictly analogous to the use of picture-writing by savage tribes. The old lady went on to explain that her old man knew no more about the news than she did, although he could read a bit: he knew that "S-t-o-k-e" spelt Guildford, but she could find her way there by the direction-post as well as he.

With regard to what was said as to the idea of the man who prepared the dress, that all the live creatures on a farm should be represented, this is doubtless the idea of 
the tradition. In Lincolnshire, representatives of all the branches of farming industry joined the procession. First came the plough, to which it was not unusual to see as many as a score of sons of the soil yoke themselves; hence the name Plough Bullocks applied to them, or, in Yorkshire, Plough Stotts. Ploughmen from neighbouring hamlets joined the procession, dressed in clean smockfrocks, decked out with ribbons by the maids. Some wore bunches of corn in their hats. Often "the procession was joined by threshers carrying their flails, reapers with sickles, and carters with their long whips, which they were ever cracking to add to the noise; while even the smith and the miller were among their number, for the one sharpened the ploughshare, and the other ground the corn." Here we have the idea of representation which we see in the dress exhibited.

The same eye-witness gives a description of a curious custom in connection with Plough-Monday, which I give in his words, as follows:- "But the great event of the day was when they came before some house which bore signs that the owner was well-to-do in the world, and nothing was given them. Bessy rattled his box and the ploughmen danced, while the country lads blew their bullocks' horns or shouted with all their might; but, if there was still no sign, no coming forth of either breadand-cheese or ale, then the word was given, the ploughshare driven into the ground before the door or window, the whole twenty men yoked pulling like one, and, in a minute or two, the ground before the house was as brown, barren, and ridgy as a newly-ploughed field. ...... We are not aware that the ploughmen were ever summoned to answer for such a breach of the law, for they. believe, to use their own expressive language, 'they' can stand by it, and no law in the world can touch 'em, 'cause it 's an old charter'."

One of the mummers in the Lincolnshire Plough-Monday procession usually wears a fox's skin in the form of a hood; 
the Bessy, a bullock's tail behind, under his gown, which he held in his hand while dancing.

From a rare book, dated in 1814 , I have the following note of the custom in Yorkshire :

"The Fool Plougr.-This is the name given to it by Struth, though it is better known in Yorkshire under the title of 'Plough Stotts'. Plough-Monday, or the first Monday after Twelfth-Day, has been considered as the ploughman's holiday, and the annexed plate represents a ludicrous procession on that day, not unlike that of the Mummers, or Morris-Dancers, at Christmas. The principal characters in this farce are the conductors of the plough; the plough-driver, with a blown bladder at the end of a stick by way of whip; the fiddler; $a$ huge clown in female attire; and the commander-in-chief, 'Captain Cauf Tail', dressed out with a cockade and a genuine calf's tail, fantastically crossed with various coloured ribands. This whimsical hero is also an orator and a dancer, and is ably supported by the manual wit of the plough-driver, who applies the bladder with great and sounding effect to the heads and shoulders of his team."

With this formless procession and dance the sword-dance became combined, as described in Young's History of Whitby, and the result of the union was the PloughMonday play. Here we have a repetition of the process I described in connection with the Easterand mumming plays. The shaping factor in folk-drama was the sword-dance, with its circle, chorus, and carefully concerted movements.

I will now read the version of the play, for which we are indebted to Mrs. Chaworth Musters. I do this because, although that lady has happily insured its preservationan act which 1 feel this Society ought gratefully to acknowledge-it is far less familiar than the mumming or Easter plays; and I think its communication this evening may strengthen my plea for the speedy and exhaustive collection of all the remains of English folk-drama still surviving. Also, it is a very pleasant tradition, which secms to take us into the midst of country life in mid-winter, a sensation which Mrs. Musters has kindly offered to allow some of us 
to realise next January. I have spoken of the modern aspect which the piece bears, but the archaism of the latter portion will be evident from my interpretation of the Easter and mumming plays.

[Extracts were read to the meeting.]

I do not think I need greatly insist on the archaism of the latter portion of this play-the episode of Beelzebub, Dame Jane, and the Doctor. It is clearly distinct in itself -as distinct as the episode of the fight between St. George and the Slasher, and the curing by the Doctor in the Easter play, which we have identified with the Summer and Winter contest of the Spring festival. It is, in fact, the same element, with modifications and change of characters : Beelzebub enacts the part of St. George, and Dame Jane that of the Slasher; though whether the episode has been imported from the Easter play, or is another version of the original, is preciscly the question for discussion. In the absence of the evidence here furnished, I can quite conceive that those who object to allow that we have in English tradition anything peculiar to the race, would give an explanation of the episode quite different from mine. The words :

\author{
"My head is made of iron, \\ My body is made of steel, \\ My hands and feet of knuckle-bone, \\ I think nobody can make me feel,"
}

which I am disposed to regard as a metaphorical description of the earth when possessed by winter, they would doubtless interpret as descriptive of armour worn by the knight. But how can that be, when the words are spoken by a female character? We may grant that in the mutations which occur in folk-drama the episode may have been imported from the Easter play without much idea of fitness; and then the question of interpretation remains as before. But if the object is to get at the root of the matter, surely we have here a good working factor in the problem; and I am by no means disposed to get rid of it, put it on 
one side, get it out of the way, by just affixing to it a label which at a glance appears to belong to it. I prefer to keep the elements before me, unlabelled, in a state of solution, ready to be readjusted in accordance with any fresh evidence that may come to hand. If I were asked to define the greatest danger which besets folk-lore, I should say it was the obvious. It was the obvious which caused the significance of children's games to be so long overlooked. It was the obvious which dismissed the Staffordshire Guisers' play as all St. George and the Dragon. It was the obvious which classified all the mumming-plays and the Easter plays as "versions of some dramatic piece written in commemoration of the Holy Wars". And I suppose Mr. Obvious, if he is here-or perhaps I should say the Messrs. Obvious-will have no patience with me because I hint that in the Easter play and this Plough-Monday play we have an episode which continues the tradition of the Summer and Winter champions.

I have a good deal to say about the character of the Doctor, which seems to be a kind of common denominator in these traditions; but I think I must leave this over. Perhaps I may have another opportunity of reading some further notes on this widely-reaching subject.

I must, however, add a few words on another topic, the Horn-Dance. I exhibit three copies of an enlargement of the photograph, kindly sent to me by Mr. Frank Udale of Uttoxeter. One of these he presents to the Society, the others he presents to me personally. I shall look forward to seeing the photograph in the collection of the Society in the proposed Album. Mr. Udale has been extremely kind in his response to my requests : I feel greatly indebted to him; and I should feel gratified if a message of recognition were sent to him by the Society. The Rev. Dr. Cox has visited Abbots Bromley to inspect the horns, and he tells me he. hàs not the slightest doubt that they are reindeer horns. This opens a vista into which at present I can only peer with the eyes of conjecture. When I have seen the 
horns and handled them-as I hope to do early in the coming summer-I will report further on the matter. Not that $I$ doubt they are reindeer horns-not for 2 moment would I doubt the deliberate opinion of Dr. Cox on such a point-but they may possibly be fossilised; in which case one's imagination would run riot over the time when the reindeer was a denizen of this land; or, turning to the alternative of their importation from Norseland, the fossilization would be fraught with possibilities of discovery as to why fossilised horns should be brought over. Again, one thinks of the reindeer tribes of France and the discoveries made by M. Lartet and Christy in the caverns of Perigord ; and the idea of relics of the Stone Age reaching this country from the south, without the least regard for one's predilection for northern origins, is quite distracting. Mr. Udale says he is "of opinion they came over at the Conquest with the Bagots-now Lord Bagot-of Blithfield, near Abbots Bromley. In his park are some goats, huge things, the descendants of a stock they brought over with them at or near the Conquest." If so, they may be relics of the reindeer tribes and the Stone Age in France? All conjecture : but conjecture is the investigator's lantern. I will read an extract from a letter which the Vicar of Abbots Bromley kindly sent me on the subject :-

"I hardly know how to begin about the Horn-Dance. I know very little about it, as I have only been here a short time; and I am sorry to say that in the time of my predecessor and his predecessor, comprising some ninety-six years, many interesting particulars about this and other matters have been allowed to die out, and details cannot now be recovered. At present, the six pairs of horns, with a bow and arrow, and the frame of a hobby-horse, are kept in the church tower, together with a curious old pot with a handle, all of wood, in which the money is collected at the dance. The Horn-Dance takes place now only on the Monday after 'Wakes' Sunday, which is the Sunday next to September $4^{\text {th. The tradition }}$ is that, some two hundred years ago, the dance took place on several consecutive Sundays, after morning service, in the churchyard- 
presumably in the summer months-and that the money so collected was devoted to the relief of the poor and the repairs of the church. When the dance began is quite unknown, but there were other places in Staffordshire where it lingered until the end of the eighteenth or beginning of this century-notably, Stafford itself, and Seighford, a small village near it. There was a special tune played for the Horn-Dance, by a man with a fiddle, within the memory of some still living; but the tune is lost, and I have quite failed to recover it: now somebody plays a concertina, with ordinary dance-music of any kind. The under-jaw of the hobby-horse is loose, and is moved with a string, so that it 'clacks' against the upper-jaw in time with the music. The same is done with the arrow and the bow. Six men have each a pair of horns; then there is a woman who holds the pot and collects the money-probably 'Maid Marian'; a lad with the bow (? Robin Hood); a jester; and another with the hobbyhorse-ten in all. They have a traditional sort of figure, which they dance over and over again. I am afraid I cannot tell you much else about the dance: we are on the borders of what used to be 'Needwood Forest', and probably it had some woodland meaning. But the curious thing is that the horns are reindeer. This has been settled quite satisfactorily just lately by Dr. Cox, the editor of The Antiguary, who came here to see them. Two pairs are very large, larger than any reindeer-horns I have ever seen myself in Russia or Norway. How they came bere is a mystery."

Whatever the origin of the horns may be, I think we need entertain little doubt that the dance was, as Mr. Bryant suggests, of some woodland character and significance; and from the bow and arrow, and the circumstance of the gifts to the poor, it seems to stand in relation to the Robin Hood epos. The presence of the hobby-horse, again, is curious. Like the Doctor, the Hobby-horse requires a paper to himself. He figures largely in the MayDay games, as well as in the winter plays; and in him, without doubt-or so it seems to me-we have the tradition of Odin's horse Sleipner; and probably his ubiquity in tradition suggests reminiscences of the other fabulous steeds of Asgard. 
Such is the view that we have been able to take of English Folk-Drama so far as is possible within the compass of a short paper. It is a diminished heritage : much had to be lost before the value of that which we are losing could make itself felt. It is for us to make the best and the most of what remains to us, and, by analysis and careful study, make good, as far as we can, what is now irrecoverable; science, I am sure, can do much to strengthen the links which have become worn and thin in the chain of our traditions; and truly it is a glorious thing to feel that we inherit a right to the mythology of the North, of which that chain is the evidence. Thanks to the peasantry of England, who have preserved the traditions which testify to our birthright! It has come to us to see and to know and to understand, and knowledge is sublime; but, in the presence of that unconscious perpetuation by generation upon generation of men and women of our race, in obedience to the instincts of their blood, I feel myself in the presence of something more than human knowledge-something mighty and organic, in which consciousness and unconsciousness are simply phases of the same thing. Let us not paralyse ourselves with doubt, but hastily snatch up all the fragments and scraps that have fallen from the table of the gods. Let us believe all to be of value rather than cast aside one morsel. We shall have ages of civilisation in which to sort out and arrange the items and squabble about interpretation. But we shall not get another Norse mythology, nor another body of English custom and tradition. It is all vanishing-quietly dying out without giving sign. I urge upon the Society to undertake immediately the thorough and systematic collection of English Folk-Dramas.

T. Fairman ORdish. 